\title{
KINERJA PETUGAS KEBERSIHAN DI DINAS LINGKUNGAN HIDUP KABUPATEN GORONTALO UTARA
}

\author{
Ririn Daulima ${ }^{1}$ \& Andi Yusuf Katili \\ STIA Bina Taruna Gorontalo \\ bukujurnalstia@binataruna.ac.id ${ }^{1}$ \& yusuf2801@gmail.com ${ }^{2}$
}

\begin{abstract}
ABSTRAK
Penelitian ini bertujuan untuk mengetahui kinerja petugas kebersihan di Dinas Lingkungan Hidup Kabupaten Gorontalo Utara. Metode penelitian menggunakan jenis deskriptif pendekatan kualitatif. Adapun fokus dalam penelitian ini adalah, kualitas kerja, kuantitas kerja, dan ketepatan waktu kerja. Teknik pengumpulan data dilakukan melalui wawancara mendalam kepada sejumlah informan, observasi dan pencatatan data sekunder yang berkaitan dengan permasalahan penelitian.

Hasil penelitian menyimpulkan bahwa, kualitas kerja petugas kebersihan di Dinas Lingkungan Hidup Kabupaten Gorontalo Utara belum optimal. Hal ini terlihat dari masih banyaknya sampah yang berserakan diarea kerja kantor khususnya pada jam kerja kantor. Kuantitas kerja petugas kebersihan di Dinas Lingkungan Hidup Kabupaten Gorontalo Utara belum optimal. Hal ini terlihat dari sedikitnya area kantor yang dibersihkan oleh petugas kebersihan dan ketidaksiagaan petugas kebersihan pada jam kerja dari pagi hingga jam pulang kantor. Ketepatan waktu kerja petugas kebersihan di Dinas Lingkungan Hidup Kabupaten Gorontalo Utara belum optimal. Hal ini terlihat dari penggunaan jam kerja yang tidak sesuai dengan ketentuan yang berlaku, dimana para petugas kebersihan hanya bekerja pada waktu pagi saja dan pulang jauh lebih awal dari jam kerja yang seharusnya.

Disarankan, perlunya Dinas Lingkungan Hidup Kabupaten Gorontalo Utara meningkatkan kualitas kerja petugas kebersihan dengan meningkatkan ketermpilan dan pengetahuan petugas. Perlunya Dinas Lingkungan Hidup Kabupaten Gorontalo Utara meningkatkan kuantitas kerja petugas kebersihan khususnya dalam luas area yang dibersihkan agar lebih menyeluruh di lingkungan Kantor Bupati Gorontalo Utara. Perlunya Dinas Lingkungan Hidup Kabupaten Gorontalo Utara meningkatkan ketepatan waktu kerja petugas kebersihan yang disesuaikan dengan jam kerja pegwai lainnya sesuai dengan porsinya.
\end{abstract}

Kata Kunci: Kinerja; Petugas; Kebersihan

\section{PENDAHULUAN}

Kebersihan lingkungan ialah suatu keadaan yang bebas dari kotoran seperti, debu, sampah, dan juga bau.
Indonesia khususnya, masalah kebersihan lingkungan tersebut selalu menjadi perdebatan dan juga masalah yang terus berkembang. Kasus yang menyangkut suatu masalah kebersihan 
PUBLIK: Jurnal Manajemen Sumber Daya Manusia, Administrasi dan Pelayanan Publik Sekolah Tinggi Ilmu Administrasi Bina Taruna Gorontalo Volume VI Nomor 2 Desember 2019

lingkungan pada tiap tahunnya terus meningkat.

Masalah mengenai kebersihan lingkungan yang tidak kondusif disebabkan karena masyarakat selalu tidak sadar akan baiknya kebersihan lingkungan. Tempat pembuangan juga tidak dipergunakan dan juga tidak dirawat dengan baik. Akibatnya ialah terdapat masalah penyakit seperti, diare, penyakit kulit, penyakit pernafasan dan penyakit lain yang juga disebabkan karena kurang bersihnya suatu lingkungan khususnya pada air dan juga polusi yang sering menyerang manusia.

Keberadaan sampah tidak terlepas dari adanya aktivitas manusia di berbagai sector. Sampah merupakan material sisa yang tidak diinginkan setelah berakhirnya suatu proses. Masyarakat masih beranggapan bahwa sampah sebagai barang sisa yang tidak berguna sehingga banyak yang membuang sampah tanpa dikelola dengan baik yang mengakibatkan timbulnya pencemaran. Sampai saat ini permasalahan sampah belum ditangani dengan baik.

Olehnya itu dibutuhkan peran dari pemerintah dalam hal ini Dinas Kebersihan sebagai lembaga yang berwenang dalam mengelola kebersihan lingkungan agar terciptanya lingkungan yang bersih dan nyaman. Perlu diingat bahwa setiap orang mempunyai hak untuk mendapatkan lingkungan yang bersih dan sehat, yang diatur dalam pasal 28 $\mathrm{H}$ ayat (1) Undang-Undang Dasar 1945.
Oleh karena itu, pemeintah sebagai pemegang kekuasaan tertinggi berkewajiban untuk melakukan perlindungan dan pengelolaan lingkungan hidup dalam pelaksanaan pembangunan dan menunjang hidup rakyat Indonesia serta makhluk hidup lainnya demi kelangsungan dan peningkatan kualitas hidup. Pemerintah dalam melaksanakan kegiatan pembangunan berkelanjutan, memanfaatkan dan mengelolah sumber daya alam yang sesuai dengan keserasian, kesalarasan dan keseimbangan lingkungan hidup.

Kegiatan pembangunan yang semakin tahun semakin meningkat tentu tidak lepas dari resiko pencemaran dan perusakan lingkungan hidup. Timbulnya dampak terhadap lingkungan hidup mendorong untuk makin diperlukannya upaya untuk pengendalian pencemaran lingkungan hidup, khususnya dalam pengendalian dan pengelolaan sampah, sesuai dengan pasal 13 ayat (1) UndangUndang Nomor 32 Tahun 2009 tentang Perlindungan dan pengelolaan Lingkungan Hidup (UU PPLH) bahwa pengendalian pencemaran dan/atau kerusakan lingkungan hidup dilaksanakan dalam rangka pelestarian fungsi lingkungan hidup.

Pencemaran lingkungan hidup banyak terjadi di berbagai kota atau Kabupaten di Indonesia. Tak terkecuali di daerah yang jauh dari hiruk pikuk ibu kota Negara yakni Kabupaten Gorontalo Utara Provinsi Gorontalo. Permasalahan sampah di wilayah ini juga sangat 
PUBLIK: Jurnal Manajemen Sumber Daya Manusia, Administrasi dan Pelayanan Publik Sekolah Tinggi Ilmu Administrasi Bina Taruna Gorontalo Volume VI Nomor 2 Desember 2019

memprihatinkan. Permasalahan sampah tidak hanya terjadi pada tempat-tempat keramaian seperti pasar tetapi juga terjadi pada lingkungan yang semestinya bersih karena di huni oleh orang-orang berpendidikan.

Seperti yang terjadi pada lingkup Dinas Lingkungan Hidup Kabupaten Gorontalo Utara, dimana sampah masih dengan sangat mudah dijumpai. Permasalahan sampah di lingkungan Dinas Lingkungan Hidup Kabupaten Gorontalo Utara tidak hanya menimbulkan kesan tidak bersih tetapi juga membangun persepsi masyarakat akan ketidakpedulian orang-orang yang ada di dalamnya terhadap lingkungan sekitarnya. Pengendalian dan pengelohan sampah yang ada di lingkungan Dinas Lingkungan Hidup Kabupaten Gorontalo Utara, tentu berada di pundak Dinas Lingkungan Hidup sebagai perangkat pemerintah daerah yang berkewajiban melaksanakan dan menjaga kelestarian lingkungan dengan memaksimalkan kinerja para petugas kebersihan. Adapun jumlah tenaga kebersihan sebanyak 13 orang yang harus memberishkan keseluruhan area perkantoran di Kantor Bupati Gorontalo Utara.

Berdasarkan hasil observasi penulis menunjukkan bahwa kinerja petugas kebersihan di lingkungan Dinas Lingkungan Hidup Kabupaten Gorontalo Utara belum optimal. Hal ini dapat terlihat dari kualitas kebersihan lingkungan Sekretariat Daerah Kabupaten Gorontalo Utara. Tampak masih banyak sampah- sampah baik sampah organik maupun non organik yang berserakan pada saat jam kerja berlangsung. Ini dikarenakan jam kerja petugas kebersihan yang hanya berlangsung pada saat pagi saja. Selain aspek kualitas, tampak petugas kebersihan juga tidak optimal dalam hal kuantitas kerja, dimana dari luas aera lingkungan Sekretariat Daerah Kabupaten Gorontalo Utara, hanya di depan kantor Bupati saja yang dimaksimalkan sementara sampahsampah tampak menumpuk di area belakang dan samping. Aspek terakhir yang dianggap belum optimal adalah pemanfaatan waktu kerja. Petugas kebersihan di lingkungan Dinas Lingkungan Hidup Kabupaten Gorontalo Utara hanya bekerja di waktu pagi yakni dari jam setengah enam hingga jam setengah sembilan pagi, sementara pada waktu menjelang siang hingga sore, tidak tampak lagi ada petugas kebersihan. Hal ini tidak sesuai jam kerja petugas kebersihan sebagaimana yang telah diatur oleh Dinas Lingkungan Hidup Kabupaten Gorontalo Utara tentang jam kerja petugas kebersihan yakni pada pagi hari, siang dan sore hari.

Dari uraian latar belakang ini, penulis tertarik untuk melakukan penelitian yang lebih dalam untuk mendapatkan gambaran yang lebih jelas dengan mengangkat judul "Kinerja Petugas Kebersihan di Dinas Lingkungan Hidup Kabupaten Gorontalo Utara". 
PUBLIK: Jurnal Manajemen Sumber Daya Manusia, Administrasi dan Pelayanan Publik Sekolah Tinggi Ilmu Administrasi Bina Taruna Gorontalo Volume VI Nomor 2 Desember 2019

\section{PERMASALAHAN}

Adapun rumusan masalah ini disesuaikan dengan latarbelakang dan identifikasi masalah sebelumnya yaitu; Bagaimana Kinerja Petugas Kebersihan di Dinas Lingkungan Hidup Kabupaten Gorontalo Utara?

\section{Tujuan Penelitian}

Berdasarkan rumusan masalah di atas, maka tujuan penelitian ini adalah untuk mengetahui Kinerja Petugas Kebersihan di Dinas Lingkungan Hidup Kabupaten Gorontalo Utara.

\section{Fokus Penelitian}

Berdasarkan penjelasan pada bab dan sub bab sebelumnya di atas, maka peneliti melakukan fokus penelitian sebagai berikut:

\section{Kualitas Kerja}

Yaitu upaya dari petugas kebersihan dalam menciptakan kebersihan lingkungan yang nyaman dan asri di Dinas Lingkungan Hidup Kabupaten Gorontalo Utara.

\section{Kuantitas Kerja}

Yaitu upaya dari petugas kebersihan dalam menciptakan kebersihan lingkungan yang nyaman dan asri secara menyeluruh di Dinas Lingkungan Hidup Kabupaten Gorontalo Utara.

\section{Ketepatan Waktu Kerja}

Yaitu upaya dari petugas kebersihan dalam melaksanakan tugasnya secara tepat waktu di Dinas Lingkungan Hidup Kabupaten Gorontalo Utara.

\section{METODE PENELITIAN}

\section{Jenis Penelitian}

Metode yang digunakan dalam penelitian ini adalah deskriptif dengan pendekatan kualitatif. Dimana suber data berasal dari data primer dan data sekunder. Teknik pengumpulan data dilakukan melalui observasi, wawancara, dan dokumentasi. Sementara teknik analisis data mengacu pada pendapat Menurut Miles dan Huberman (dalam Sugiyono, 2013:337), yaitu: Reduksi data, Penyajian data, dan Verifikasi.

\section{HASIL PENELITIAN DAN PEMBAHASAN}

Kinerja dapat diartikan sebagai perilaku berkarya, berpenampilan atau berkarya. Kinerja merupakan bentuk bangunan organisasi yang bermutudimensional, sehingga cara mengukurnya bervariasi tergantung pada banyak faktor. Pengertian kinerja adalah hasil kerja organisasi dalam mewujudkantujuan yang ditetapkan organisasi, kepuasan pelanggan serta kontribusinyaterhadap perkembangan ekonomi masyarakat tempat organisasi.Indikator kinerja organisasi adalah ukuran kuantitatif maupun kualitatifyang dapat menggambarkan tingkat pencapaian sasaran dan tujuan. Untukmengetahui kinerja pelayanan dapat dilihat dari seberapa besar output, semakinbesar volume output berarti semakin tinggi pula tingkat kinerjanya. 
Secara umum dapat dinyatakan empat aspek dari kinerja yaitu sebagai berikut : (1) Kuantitas. Kuantitas kerja berarti petugas harus sekuat tenaga untuk mencapai hasil kerja yang sesuai dengan target. Artinya, Petugas harus selalu menyiapkan kondisi tubuh yang kuat dan sehat, kondisi perasaan dan emosi yang penuh semangat, kondisi pikiran yang jernih, tenang, dan kreatif. (2) Kualitas. Kualitas kerja berarti karyawan harus memiliki keterampilan, pengetahuan, dan niat baik untuk bekerja dengan berkualitas, rapi, bersih, teliti, dan indah. (3) Ketepatan Waktu. Pemanfaatan waktu adalah tingkat aktivitas yang diselesaikan pada awal waktu yang dinyatakan, dilihat dari sudut koordinasi dengan hasil output serta memaksimalkan waktu yang tersedia untuk aktivitas lain.

Dalam penelitian ini akan dibahas tentang kinerja petugas kebersihan di Dinas Lingkungan Hidup Kabupaten Gorontalo Utara, dengan fokus penelian yakni: Kualitas Kerja, Kuantitas Kerja dan Ketepatan Waktu Kerja.

Kualitas kerja merupakan taraf, tingkat baik buruknya suatu hasil kerja seseorang dengan ukuran yang sudah ditetapkan sebelumnya. Kualitas kerja menyangkut mutu seorang pegawai atau karyawan dalam melaksanakan tugas-tugasnya meliputi kesesuaian, kerapian, dan kelengkapan.

Kualitas (Quality) kerja adalah segala bentuk satuan ukuran yang terkait dengan mutu atau kualitas hasil kerja dan dinyatakan dalam ukuran angka atau yang dapat dipadankan dengan angka". "Quality of work (kualitas kerja) menunjukkan sejauh mana mutu seorang pegawai dalam melaksanakan tugas-tugasnya meliputi ketepatan, kelengkapan, dan kerapian".

Adapun kualitas kerja yang dimaksud dalam penelitian ini adalah upaya dari petugas kebersihan dalam menciptakan kebersihan lingkungan yang nyaman dan asri di Dinas Lingkungan Hidup Kabupaten Gorontalo Utara. Berdasarkan hasil penelitian dan analisis penulis dapat diketahui bahwa kualitas kerja petugas kebersihan di Dinas Lingkungan Hidup Kabupaten Gorontalo Utara belum optimal. Hal ini terlihat dari masih banyaknya sampah yang berserakan diarea kerja kantor khususnya pada jam kerja kantor.

Kuantitas kerja merupakan segala bentuk satuan ukuran yang terkait dengan jumlah hasil kerja dan dinyatakan dalam ukuran angka atau yang dapat dipadankan dengan angka". Quantity of Work (kuantitas kerja) adalah jumlah kerja yang dilaksanakan oleh seseorang pegawai dalam suatu periode tertentu. Hal ini dapat dilihat dari hasil kerja pegawai dalam kerja penggunaan waktu tertentu dan kecepatan dalam menyelesaikan tugas dan tanggung jawabnya." Dengan demikian kuantitas kerja dapat dilihat dari jumlah kerja dan penggunaan waktu. Jumlah kerja adalah banyaknya tugas pekerjaanya, dapat dikerjakan. Penggunaan waktu adalah banyaknya waktu yang digunakan dalam menyelesaikan tugas dan pekerjaan. 
PUBLIK: Jurnal Manajemen Sumber Daya Manusia, Administrasi dan Pelayanan Publik Sekolah Tinggi Ilmu Administrasi Bina Taruna Gorontalo Volume VI Nomor 2 Desember 2019

Adapun kuantitas kerja yang dimaksudkan dalam penelitian ini adalah upaya dari petugas kebersihan dalam menciptakan kebersihan lingkungan yang nyaman dan asri secara menyeluruh di Dinas Lingkungan Hidup Kabupaten Gorontalo Utara. Berdasarkan hasil penelitian dan analisis penulis dapat diketahui bahwa kuantitas kerja petugas kebersihan di Dinas Lingkungan Hidup Kabupaten Gorontalo Utara belum optimal. Hal ini terlihat dari sedikitnya area kantor yang bisa dibersihkan oleh petugas kebersihan dan ketidaksiagaan petugas kebersihan pada jam kerja dari pagi hingga jam pulang kantor.

Ketepatan Waktu Kerja. Waktu merupakan hal yang terpenting dalam kehidupan. Merugilah orang-orang yang tidak dapat memanfaatkan waktunya dengan optimal. Untuk itu diperlukan suatu pengelolaan atau manajemen waktu yang tepat dalam menjalankannya. Sebagai seorang petugas yang bertugas memberikan pelayanan pada orang banyak, sangat diharapkan untuk dapat meningkatkan kinerja atau prestasi kerjanya . Prestasi kerja pegawai ini salah satunya dapat dicapai melalui pemanfaatan manajemen waktu yang baik. Menajemen waktu yang tepat dapat mengurangi terbuangnya waktu kerja dengan sia-sia, sehingga kinerja atau prestasi kerja dapat diraih dengan maksimal.

Ketepatan waktu kerja yang dimaksud dalam penelitian ini adalah upaya dari petugas kebersihan dalam melaksanakan tugasnya secara tepat waktu di Dinas Lingkungan Hidup Kabupaten Gorontalo Utara. Berdasarkan hasil penelitian dan analisis penulis dapat diketahui bahwa ketepatan waktu kerja petugas kebersihan di Dinas Lingkungan Hidup Kabupaten Gorontalo Utara belum optimal. Hal ini terlihat dari penggunaan jam kerja yang tidak sesuai dengan ketentuan yang berlaku, dimana para petugas kebersihan hanya bekerja pada waktu pagi saja dan pulang jauh lebih awal dari jam kerja yang seharusnya.

\section{SIMPULAN}

Berdasarkan hasil penelitian dan pembahasan yang telah dipaparkan sebelumnya, dapat disimpulkan hal-hal sebagai berikut :

1. Kualitas kerja petugas kebersihan di Dinas Lingkungan Hidup Kabupaten Gorontalo Utara belum optimal. Hal ini terlihat dari masih banyaknya sampah yang berserakan diarea kerja kantor khususnya pada jam kerja kantor.

2. Kuantitas kerja petugas kebersihan di Dinas Lingkungan Hidup Kabupaten Gorontalo Utara belum optimal. Hal ini terlihat dari sedikitnya area kantor yang dibersihkan oleh petugas kebersihan dan ketidaksiagaan petugas kebersihan pada jam kerja dari pagi hingga jam pulang kantor.

3. Ketepatan waktu kerja petugas kebersihan di Dinas Lingkungan Hidup Kabupaten Gorontalo Utara belum optimal. Hal ini terlihat dari 
PUBLIK: Jurnal Manajemen Sumber Daya Manusia, Administrasi dan Pelayanan Publik Sekolah Tinggi Ilmu Administrasi Bina Taruna Gorontalo Volume VI Nomor 2 Desember 2019

penggunaan jam kerja yang tidak sesuai dengan ketentuan yang berlaku, dimana para petugas kebersihan hanya bekerja pada waktu pagi saja dan pulang jauh lebih awal dari jam kerja yang seharusnya.

\section{SARAN}

Berdasarkan simpulan tersebut, maka dapat disarankan hal-hal sebagai berikut:

1. Perlunya arahan dari Dinas Lingkungan Hidup Kabupaten Gorontalo Utara untuk meningkatkan kualitas kerja petugas kebersihan melalui peningkatan ketermpilan dan pengetahuan petugas kebersihan.

2. Perlunya pengawasan oleh Dinas Lingkungan Hidup Kabupaten Gorontalo Utara dalam meningkatkan kuantitas kerja petugas kebersihan khususnya dalam luas area yang dibersihkan agar petugas bisa bekerja lebih efektif dan efesien.

3. Perlunya evaluasi oleh Dinas Lingkungan Hidup Kabupaten Gorontalo Utara meningkatkan ketepatan waktu kerja petugas kebersihan yang disesuaikan dengan jam kerja pegawai lainnya sesuai dengan porsinya agar disiplin petugas kebersihan meningkat

\section{DAFTAR PUSTAKA}

Abe, Alexander. 2011. Perencanaan Daerah Partisipatif. Yogyakarta: IRE Press.
Barbara, Kozier. 2008. Fundamental of Nursing. Seventh Edition, Vol.2. Jakarta: EGC.

Endang, Sri Nuryani. 2012. Peran Pemerintah Dalam Pengembangan UKM Menghadapi Pasar Global.” Makalah disampaikan pada Seminar UKM Yogyakarta.

Hasibuan, Malayu S.P, 2009. Manajemen Sumber Daya Manusia. Edisi Revisi. Jakarta: PT. Bumi Aksara.

Imawan, Riswandha. 2010. Pembanguna Politik, Demokratisasi dan integrasi nasional. Yogyakarta: Pustaka Pelajar.

Irawan Soehartono. 2009. Metode Penelitian Sosial. Bandung: PT Remaja Rosdakarya.

Mankiw N, Gregory, dkk. 2012, Pengantar Ekonomi Makro. Jakarta: Salemba Empat.

Manullang, 2012. Dasar-dasar Manajemen Bagi Pimpinan Perusahaan. Jakarta: Gajah Mada Press.

Mudrajat Kuncoro. 2008. Metode Riset Untuk Bisnis dan Ekonomi. Jakarta: Erlangga.

Murni Asfia. 2008. Ekonomika Makro, Jakarta: PT. Refika Aditama.

Nanga, Muana. 2009. Teori Makro Ekonomi. Edisi Pertama. Jakarta: Rajawali Press.

Nur Indriantoro dan Bambang Supomo. 2009. Metodologi Penelitian Bisnis. Yogyakarta: BPFE. 
Pulukadang, Ishak. 2010. Makalah; Mewujudkan Good Governance

Melalui Pelayanan Publik.

Manado: FISIP Unsrat.

Siagian Sondang, 2008.

Kepemimpinan Organisasi dan

Perilaku Administrasi. Jakarta:

Penerbit Gunung Agung.

Soekanto, Soerjono, 2012, Teori

Peranan. Jakarta: Bumi Aksara.

Sugiyono. 2013. Metode

Penelitian Pendidikan

Pendekatan Kuantitatif,

kualitatif, dan R\&D. Bandung:

Alfabeta.

Sukirno, Sadono. 2010. Makro

Ekonomi: Teori Pengantar. Edisi

3. Jakarta: Rajawali Pers.

Tjokroamidjojo, Bintoro. 2009. Good

Governance, Paradigma Baru

Ilmu Pemerintahan. Jakarta:

ISBM.

Wahab Abdul Azis, 2008. Anatomi

Organisasi dan Kepemimpinan

Pendidikan. Bandung: Alfabeta

Zulkarnain, 2009. Kendala

Terwujudnya Good Governance.

Bone: Artikel.

\section{Sumber Lain;}

Undang-Undang Nomor 9 tahun 1995

tentang ciri-ciri usaha kecil

Undang-Undang Nomor 20 Tahun

2008 tentang Usaha Kecil

Menengah (UKM). 